AJIE - Asian Journal of Innovation and Entrepreneurship

(e-ISSN: 2477-0574 ; p-ISSN: 2477-3824)

Vol. 01, No. 02, May 2016

\title{
ANALISIS FAKTOR PEMBENTUK E-LOYALTY
}

\author{
Hapsari Yuli Widowati \\ Magister Management Universitas Sebelas Maret \\ Email: yuli200787@yahoo.co.id
}

\begin{abstract}
E-loyalty establishment issue is very interesting to study, because loyalty can improve a product's profitability. This research aimed to explain the effect of (1) service quality on consumer loyalty, (2) service quality on consumer satisfaction, (3) service quality on trust, (4) service quality on commitment, (5) consumer satisfaction on consumer loyalty, (6) trust on consumer loyalty, and (7) commitment on consumer loyalty. The sample consisted of 200 respondent intending to make online purchase loyally taken using purposive sampling technique. SEM (Structural Equation Model) was a statistical instrument chosen to find out the relationship between variables. The result of research indicated that (1) service quality affected consumer loyalty insignificantly, (2) service quality affected consumer satisfaction significantly and positively, (3) service quality affected trust significantly and positively, (4) service quality affected consumer commitment significantly and positively, (5) service quality affected consumer loyalty significantly and positively, (6) trust affected consumer loyalty insignificantly, and (7) commitment affected consumer loyalty significantly and positively. In addition, this research also discussed the insignificant relationship between variables, research implication whether theoretically, methodologically or practically, and recommendation for further research.
\end{abstract}

Keywords: service quality, consumer satisfaction, trust, commitment, loyalty.

\begin{abstract}
ABSTRAK
Isu dalam pembentuk E-loyalty sangat menarik untuk diteliti, karena melalui loyalitas dapat meningkatkan profitabilitas suatu produk. Ada beberapa tujuan yang ingin dicapai yaitu untuk menjelaskan (1) kualitas layanan terhadap loyalitas konsumen, (2) kualitas layanan terhadap kepuasan konsumen, (3) kualitas layanan terhadap kepercayaan, (4) kualitas layanan terhadap komitmen, (5) kepuasan konsumen terhadap loyalitas konsumen, (6) kepercayaan terhadap loyalitas konsumen, (7) komitmen terhadap loyalitas konsumen. Sampel yang berjumlah 200 responden berniat lotal untuk pembelian melalui online diambil dengan menggunakan teknik purposive sampling. SEM (Structural Equation Model) merupakan alat statistik yang dipiluh untuk mengetahui hubungan antar variabel. Hasil mengindikasikan bahwa (1) kualitas layanan tidak signifikan berpengaruh pada loyalitas konsumen, (2) kualitas layanan positif dan signifikan pada kepuasan konsumen, (3) kualitas layanan positif dan signifikan pada kepercayaan, (4) kualitas layanan positif dan signifikan pada komitmen konsumen, (5) kepuasan konsumen positif dan signifikan pada loyalitas konsumen, (6) kepercayaan tidak signifikan berpengaruh pada loyalitas konsumen, (7)
\end{abstract}


komitmen positif dan signifikan pada loyalitas konsumen. Selain itu, dalam penelitian ini juga mendiskusikan mengenai hubungan antar variabel yang tidak signifikan, implikasi penelitian baik secara teoritis, motodologi, maupun praktis serta saran untuk penelitian selanjutnya.

Kata kunci: kualitas pelayanan, kepuasan pelanggan, kepercayaan, komitmen, loyalitas

\section{PENDAHULUAN}

Loyalitas konsumen merupakan isu yang relatif penting untuk diteliti karena kemanfaatannya dalam peningkatan kinerja perusahaan (Aaker, 1991). Dengan loyalitas inilah yang menjadi penentu apakah suatu produk dapat diterima pasar atau tidak. Hal ini juga berlaku pada transaksi penjualan secara online. Seperti yang diketahui secara umum bahwa suatu transaksi penjualan dilakukan secara langsung, secara langsung di sini diartikan baik si penjual maupun si pembeli bertemu secara langsung untuk melakukan suatu transaksi penjualan. Di mana si penjual dan si pembeli, mereka masing-masing saling mengetahui keadaan secara nyata barang yang akan diperjual-belikan. Seiring dengan berkembangnya teknologi dan semakin tingginya kesibukan seseorang maka terjadilah perubahan dalam transasksi penjualan tersebut. Perubahan transaksi penjualan tersebut dapat berlangsung tanpa adanya proses bertemu langsung antara si penjual dan si pembeli. Dengan sistem transaksi seperti ini, si penjual dan si pembeli hanya bertemu melalui sarana media online saja, sehingga si pembeli tidak mengetahui secara langsung kondisi barang yang akan dibelinya. Sehingga dengan adanya transaksi pembelian secara online maka pastinya akan mempengaruhi loyalitas dari konsumen tersebut.

$$
\text { Loyalitas pada umumnya }
$$

ditunjukkan dalam niat pembelian kembali dan keinginan untuk merekomendasikan kepada orang lain (Gaur et al., 2011). Secara praktis studi loyalitas memiliki beberapa manfaat antara lain: loyalitas konsumen dapat menghemat biaya pemasaran, karena semakin tinggi loyalitas, maka semakin rendah biaya pemasaran yang dikeluarkan perusahaan (Aaker, 1991). Loyalitas konsumen dapat menciptakan word of mouth yang positif (Dick dan Basu, 1994). Loyalitas konsumen berpengaruh pada sensitivitas harga, semakin tinggi loyalitas, maka semakin rendah sensitivitas harga pada konsumen (Rundle \& Mackay, 2001). Loyalitas secara positif berkaitan dengan komitmen, di mana komitmen secara positif dipengaruhi oleh kepercayaan yang terbentuk (Suki, 2011). Loyalitas juga sangat ditentukan oleh persepsi dari konsumen, di mana persepsi konsumen adalah proses dimana kita memilih, mengatur dan menginterpretasikan rangsangan tersebut ke dalam gambaran yang memberikan makna dan melekat (Lamb et al, 2001). Persepsi konsumen yang memperoleh stimulus yang baik akan menimbulkan antara lain kepuasan konsumen, kepercayaan, dan komitmen (Robbins, 1998).

Dalam membangun loyalitas pada pembelian online tidaklah mudah, dibutuhkan kepuasan, kepercayaan, dan komitmen dari pelanggan pembelian online (Hahn dan Kim, 2009). Menurut Hess dan Story (2005) bahwa dalam kepercayaan dan komitmen harus dapat dikembangkan guna mencapai kepuasan 
pelanggan. Keberhasilan dari pengembangan kepuasan dan kepercayaan dapat meningkatkan formasi tampilan secara personal dan fungsional (komitmen) di antara pelanggan dan perusahaan (Sirdeshmukh et al, 2002; Burnham et al, 2003; Ndubisu, 2007; Athanasopoulou, 2009). Dalam E-Commerce, pertanyaan tentang kepuasan, kepercayaan, loyalitas merupakan hal yang sangat penting yang mendasar harus selalu ditingkatkan. Karena selama pembelian online berlangsung, kepercayaan menjadi faktor yang vital bagi pelanggan untuk mengambil keputusan pembelian, di mana dalam keputusan pembelian tersebut terdapat hal-hal yang harus dihadapi oleh pelanggan, hal-hal tersebut berupa faktor resiko produk dan fokus pada keamanan dan privasi (Winch dan Joyce, 2006; Bart et al, 2005; Connolly dan Bannister, 2008). Menurut Mukherjee dan Nath (2007) faktor kepercayaan dapat mengubah hubungan komitmen dalam interaksi yang telah berlangsung. Fokus pada kepuasan pelanggan dan kepercayaan pelanggan dapat meningkatkan kualitas hubungan terhadap pelanggan (Kim, 2002; Yoo and Park, 2005, Choi et al, 2007).

Banyak studi penelitian yang bertujuan untuk mengukur tingkat loyalitas konsumen. Diantaranya adalah penelitian menurut Czepieldan Gilmore. (1987); Caruana, (2002); Shankar et al, (2003) bentuk dari sikap loyalitas konsumen dapat dilihat salah satunya dari banyaknya barang yang dibeli dari produk tersebut atau intensitas pembelian konsumen dari produk tersebut. Penelitian lain telah menetapkan loyalitas sebagai "sikap yang menguntungkan terhadap merek yang dihasilkan dalam pembelian yang konsisten dari merek dari waktu ke waktu" (Assael,1992;Keller, 1993). Menurut
Engel, Kollat, dan Blackwell (1982) loyalitas merupakan merek sebagai "Respon yang istimewa, sikap dan perilaku terhadap satu atau lebih dalam kategori produk yang dinyatakan pada periode waktu oleh tertentu".

Menurut penelitian Hsin Hsin Chang and Hsin-Wei Wang (2011) proses sikap pembelian konsumen terdiri dari proses pengambilan keputusan (E-service quality, customer perceived value), proses reaksi sebagai mediasi (customer satisfaction), dan hasil responnya (Loyalty). Pada dasarnya evaluasi sikap konsumen pembelian online dapat melalui kepuasan konsumen, kepercayaan, dan komitmen. Menurut Szymanski and Hise (2000) terdapat empat factor penting dalam E-Satisfaction yaitu persepsi konsumen, merchandizing (terdiri dari cara pemesanan produk dan informasi produk, design / bentuk, dan keamanan. Menurut Srinivasan et al (2002) terdapat delapan factor untuk identifikasi kepuasan yaitu customization, hubungan berinteraksi, kepedulian, komunitas, convenience, culivation, pilihan dan karakter, dan yang kesemuan yaitu menjadi ukuran dalam pencapaian loyalitas dan factor tersebut menjadi skala dalam pengukurannya. Menurut Francis dan White (2002) menunjukkan terdapat enam factor untuk mengidentifikasi kepuasan yaitu fungsi dari web store, penggambaran pada atribut produk, kondisi kepemilikkan, pengiriman barang, pelayanan pada pelanggan, dan keamanan.

Berdasarkan penjelasan di atas maka dapat disimpulkan bahwa untuk mencapai loyalitas dalam pembelian online, maka padap erusahaan yang menggunakan sarana media online haruslah focus pada kepuasan pelanggan, kepercayaan, dan komitmen. Dimana 
kepuasan, kepercayaan, dan komitmen ini dipilih menjadi sarana bagi perusahaan karena dapat meminimalkan biaya-biaya dalam promosi penjualan. Dalam hal ini yang menjadi objek pengamatan pada penelitian adalah website-website yang menjual produk-produknya melalui bisnis online. Hal ini bertujuan agar model yang diuji dapat menjelaskan fenomenafenomena yang terjadi di Indonesia.

Sehingga penelitian ini bertumpu pada lima variabel amatan yaitu : kualitas layanan, kepuasan konsumen, kepercayaan, komitmen, dan loyalitas konsumen. Desain penelitian ini merupakan perpaduan model penelitian oleh Hsin Hsin Chang and Hsin-Wei Wang (2011), Ki-Han Chung and Jae-Ik Shin (2010), dan Pin Luarn (2003). Dengan demikian, model yang dikonstruksi diharapkan memiliki dayap rediksi yang tinggi terhadap loyalitas konsumen khususnya konsumen secara bisnis online shop. Berikut ini adalah penjelasan terkait pengertian dari masingmasing variabel amatan.

Pertama, kualitas konsumen menurut Zeithaml et al (2003, p.363) dapat didefinisikan bahwa fasilitas pada website sangat efisien dan efektif dalam berbelanja, pembelian, dan pengiriman barang dan jasa. Menurut Lee dan Lin (2005) faktor-faktor untuk mengidentifikasi persepsi konsumen pada kualitas layanan adalah: Desain website (Tingkat penggunandari website tersebut), reliabilitas (reliabilitas dan aman), sikap tanggap (tanggap dan mengerti apa yang diinginkan oleh konsumennya), kepercayaan (dapat dipercaya atas tawaran di website tersebut), dan personaliti (pelayanan kebutuhan pada masing-masing konsumen berbeda-beda).
Kedua, kepuasan konsumen merupakan dasar dari konsep pemasaran. Kepuasan konsumen dibutuhkan dalam mencapai loyalitas konsumen. Kepuasan konsumendapat didefinisikan sebagai reaksi konsumen dalam konteks pemenuhan kebutuhan dasar, dan konsumen sebagai penentu atas pemenuhan kebutuhan tersebut (Oliver, 1997). Dari definisi tersebut baik hasilnya positif maupun negatif ini berdasarkan atas perasaan yang ditimbulkan atas nilai dari pelayanan yang telah diberikan (Woodruff, 1997). Menurut Anderson dan Srinivasan (2003) Kepuasan konsumen dapat didefinisikan sebagai konten konsumen atas tanggapan kosumen dalam pembelian secara berulang dengan menggunakan salah satu media elektronik. Kepuasan konsumen sangat berkaitan erat dengan loyalitas konsumen. Semakin tinggi kepuasan konsumen maka semakin tinggi pula tingkat loyalitas konsumen tersebut.

Ketiga, Kepercayaan dapat didefinisikan dalam berbagai jalan dalam menjalin hubungan dengan para pemasar dengan menggunakan sarana: "sebagai rekan kerja yang nyaman dan menguntungkan" (Moorman et al, 1992) dan "sebagai rekan yang percaya atas setiap janji yang telah diucapkan atas kesanggupan yang telah menjadi kesepakatan" (Wong dan Sohal, 2006). Kepercayaan menurut Murkherjee dan Nath (2007), sangat penting guna menjalin hubungan yang dapat digunakan sebagai strategi. Kepercayaan dan kepuasan menjadi titik terpenting dalam pemasaran.

Keempat, komitmen merupakan simbol baik secara implisit maupun eksplisit pada jaminan pelayanan pemasaran, yang bertujuan untuk memenuhi kebutuhan konsumen (Wu et al, 2009). Komitmen akan berjalan secara 
terus-menerus dibangun atas hubungan yang telah terjalan lama (Meyer et al, 2009). Menurut Mukherjee dan Nath (2007) dalam pemasaran secara online komitmen dapat dibentuk melalui hubungan antara si pemasar dengan para konsumennya guna mencapai komitmen yang efektif. Kepercayaan dan kepuasan merupakan kombinasi guna memenuhi kebutuhan dari para konsumennya (Bhattacharya dan Sen, 2003; Fullerton, 2003; Morgan dan Hunt, 1999; Parvatiyar and Sheth, 2001; Sirdeshmukh et al, 2002).

Kelima, loyalitas konsumen menurut Oliver dalam Kotler (2009: 138) loyalitas adalah komitmen yang dipegang secara mendalam untuk membeli atau mendukung kembali produk atau jasa yang disukai di masa depan meski pengaruh situasi usaha pemasara berpotensi menyebabkan pelanggan beralih. Menurut Jacob (1971) loyalitas didasarkan pada proses sikap untuk kembali yang bersumber atas kesadaran diri itu sendiri. Penelitian lain mengungkapkan bahwa suatu hasil proses dari sikap untuk memilih sesuatu yang paling disukai yang berdasarkan atas hasil konsistensi dalam jangka waktu tertentu (Assael, 1992, Keller, 1993).

Berdasarkan latar belakang di atas yang disesuaikan dengan teori penelitian yang telah dikemukakan, peneliti membuat model yang menguji analisis faktor-faktor pembentuk dalam loyalitas konsumen (Eloyalty). Judul ini diambil dengan alasan terdapat 5 faktor pembentuk dalam loyalitas konsumen (E-loyalty). Sehingga dapat diketahui faktor-faktor pembentuk mana saja yang kuat dalam pembentuk loyalitas konsumen (E-loyalty). Karena alasan tersebut peneliti tertarik untuk memilih faktor pembentuk loyalitas dalam transaksi pembelian online.

\section{KAJIAN TEORI}

\section{Pengertian Kualitas layanan}

Kualitas layanan dan kepuasan konsumen mempunyai hubungan atau keterkaitan yang kuat. Beberapa studi empiris telah dilakukan untuk menentukan variabel-variabel kualitas layanan. Hal tersebut banyak dilakukan para peneliti dengan cara mengeksplorasi mengenai faktor-faktor yang mendukung kualitas layanan.

Secara umum, kualitas layanan diartikan sebagai perbedaan antara harapan konsumen mengenai layanan yang akan diterima dan persepsi layanan yang diterima (Gronroos, 2001; Parasuraman, Zethaml dan Berry, 1988). Suatu kualitas layanan pada umumnya didasarkan pada interaksi antara konsumen dan produsen suatu produk tertentu (Gronross 1982; Lehtinen dan Lehtinen 1982; Lewis dan 1983; Parasuraman, Zeithaml, dan Berry 1985; Sasser, Olsen, dan Wyckoff 1978).

Menurut Parasuraman (Tjiptono, 2005) mengidentifikasi lima dimensi kualitas pelayanan (SERVQUAL) yaitu:

a. Reliability (Keandalan): Berkaitan dengan kemampuan perusahaan untuk memberikan layanan yang akurat sejak pertama kali tanpa membuat kesalahan apapun dan menyampaikan jasanya sesuai dengan waktu yang disepakati.

b. Responsiveness (daya tanggap): Berkenaan dengan kesediaan dan kemampuan pada karyawan untuk membantu para pelanggan dan meespon permintaan merka, serta menginformasikan kapan jasa akan diberikan dan kemudian memberikan jasa secara cepat. 
c. Assurance(Jaminan): Perilaku karyawan mampu menumbuhkan kepercayaan pelanggan terhadap perusahaan dan perusahaan bisa menciptakan rasa aman bagi pelanggan. Jaminan juga berarti bahwa para karyawan selalu bersikan sopan dan menguasai oengetahuan dan keterampilan yang dibutuhkan untuk menangani setiap pertanyaan atau masalah pelanggan.

d. Empathy (Empati): Perusahaan memahami masalah para pelanggannya dan bertindak demi kepentingan pelanggan, serta memberikan perhatian personal kepada para pelanggan dan memiliki jamoperasi yang nyaman.

e. Tangible (berwujud): Berkenaan dengan daya tarik fasilitas fisik, perlekapan, dan material yang digunakan perusahaan, serta penampilan karyawan.

\section{Pengertian Kepuasan Konsumen}

Secar umum, kepuasan pelanggan ditentukan oleh terpenuhi atau tidaknya harapan pelanggan. Kepuasan merupakan fungsi dari kesan kinerja dan harapan. Jika kinerja berada di bawah harapan, maka pelanggan merasa tidak puas. Jika melebihi harapan, pelanggan amat puas. Menurut Kotler (2002) bahwa kepuasan adalah perasaan senang atau kecewa seseorang yang muncul setelah membandingkan atara persepsi atau kesannya terhadap kinerja (atau hasil) suatu produk dan harapan-harapannya. Oliver (dalam Tjiptono dan Chandra, 2005) mengemukakan bahwa kepuasan konsumen adalah penilaian bentuk atau model produk atau jasa yang berkaitan dengan konsumsi yang menyenangkan.

Kepuasan konsumen merupakan dasar dari konsep pemasaran. Kepuasan konsumen dibutuhkan dalam mencapai loyalitas konsumen. Menurut Kotler (2009) kepuasan adalah perasaan senang atau kecewa seseorang yang timbul karena membandingkan kinerja yang dipersepsikan produk atau jasa (atau hasil) terhadap ekpektasi mereka. Kepuasan konsumen dapat didefinisikan sebagai reaksi konsumen dalam konteks pemenuhan kebutuhan dasar, dan konsumen sebagai penentu atas pemenuhan kebutuhan tersebut (Oliver, 1997). Dari definisi tersebut baik hasilnya positif maupun negatif ini berdasarkan atas perasaan yang ditimbulkan atas nilai dari pelayanan yang telah diberikan (Woodruff, 1997). Menurut Anderson dan Srinivasan (2003) Kepuasan bisnis elektronik dapat didefinisikan sebagai konten konsumen atas tanggapan kosumen dalam pembelian secara berulang dengan menggunakan salah satu media elektronik. Menurut McKinney et al (2002) posisi konsumen adalah media elektronik dapat bersumber melalui dua sumber yaitu :

a. Kepuasan dengan informasi yang berkualitas dalam konten website tersebut.

b. Kepuasan dengan sistem tampilan dari website yang dapat memberikan penghantar informasi.

Secara keseluruhan kepuasan didefinisikan sebagai pernyataan afektif tentang reaksi emosional terhadap pengalaman atas produk atau jasa, yang dipengaruhi oleh kepuasan pelanggan terhadap produk tersebutdan dengan informasi yang digunakan untuk memilih produk.

\section{Pengertian Kepercayaan}

Lau dan Lee mendefinisikan kepercayaan sebagai 
kesediaan seseorang untuk menggantungkan dirinya pada pihak lain dengan resiko tertentu. Kepercayaan juga diartikan sebagai kesediaan seseorang untuk menggantungkan dirinya pada pihak lain yang terlibat dalam pertukaran karena ia mempunyai keyakinan kepada pihak lai tersebut (moorman, Deshpande, dan Zaltman dalam Darsono dan Dharmmesta, 2005). Kepercayaan akan terjadi ketika terdapat kenyamanan pada reliabilitas dan integritas (Crosby et al, 1990; Morgan dan Hunt, 1994; Palmatier et al, 2006). Kepercayaan dalam dunia bisnis dipandang sebagai salah satu antesedent stabil yang paling relevan dan hubungan kolaboratif. Kepercayan secara umum adalah penting untuk membangun dan memelihara hubungan jangka panjang (Rousseau, Sitkin, Burt, \& Camerer, 1998; Singh \& Sir deshmukh, 2000). Sementara kepercayaan didefinisikan Moorman, Deshpande, dan Zaltman (1993) disebut kesediaan mengandalkan pada mitra pertukaran di mana satu dengan yang lain memiliki keyakinan. Menurut Lau dan Lee (1999), jika salah satu pihak memiliki kepercayan pada pihak lain yang akhirnya menimbulkan niat perilaku positif terhadap pihak kedua.

Kepercayaan dapat didasarkan sebagai suatu yang penting untuk kesuksesan pemasaran secara elektronik. Transaksi secara online dan hubungan dengan para konsumen tidak menjadi satu-satunya yang menjadi karakteristik tetapi juga kesamaan menjaga kontrol dan kesempatan dalam peluang yang dapat menimbulkan resiko, dan menjadi elemen kepercayaan yang penting dalam pemasaran (Grabner-Krauter dan Kaluscha, 2003). Kepercayaan dapat didefinisikan dalam berbagai jalan dalam menjalin hubungan dengan para pemasar dengan menggunakan sarana: "sebagai rekan kerja yang nyaman dan menguntungkan" (Moorman et al, 1992) dan "sebagai rekan yang percaya atas setiap janji yang telah diucapkan atas kesanggupan yang telah menjadi kesepakatan" (Wong dan Sohal, 2006). Kepercayaan menurut Murkherjee dan Nath (2007), sangat penting guna menjalin hubungan yang dapat digunakan sebagai strategi. Kepercayaan dan kepuasan menjadi titik terpenting dalam pemasaran.

\section{Pengertian Komitmen}

Telah banyak penelitian yang menemukan bahwa komitmen merupakan komponen utama dan yang menentukan awetnya suatu hubungan pemasaran diantara bisnis-bisnis yang sejenis (Cater dan Zabkar, 2008). Komitmen merupakan simbol baik secara implisit maupun eksplisit pada jaminan pelayanan pemasaran, yang bertujuan untuk memenuhi kebutuhan konsumen (Wu et al, 2009). Komitmen akan berjalan secara terus-menerus dibangun atas hubungan yang terjalan telah lama (Meyer et al, 2009). Menurut Mukherjee dan Nath (2007) dalam pemasaran secara online komitmen dapat dibentuk melalui hubungan antara si pemasar dengan para konsumennya guna mencapai komitmen yang efektif. Kepercayaan dan kepuasan merupakan kombinasi guna memenuhi kebutuhan dari para konsumennya (Bhattacharya dan Sen, 2003; Fullerton, 2003; Morgan dan Hunt, 1999; Parvatiyar dan Sheth, 2001; Sirdeshmukh et al, 2002). 
Dalam pemasaran jasa, komitmen ini dirumuskan sebagai bentuk perjanjian yang tersurat maoun tersirat untuk melanjutkan hubungan antar dua pihak atau lebih "implicit and or explicit of relational continuity between exchange partners" (Dwyer et al, 1987). Komitmen dalam konsep long term relationship, memegang peranan yang sangat penting karena hubungan jangka panjang paling banyak didasarkan kepada komitmen kedua belah pihak. Moorman et al (1992) mendefinisikan commitement as : "an enduring desire to maintain a valued relationship." Definisi ini lebih menekankan pengertian komitmen dari unsur perilaku sebagai upaya untuk mempertahankan dan menjaga hubungan jangka panjang antara kedua belah pihak agar hubungan ini lebih bernilai.

\section{Pengertian Loyalitas Konsumen}

Menurut Oliver dalam Kotler (2009: 138) loyalitas adalah komitmen yang dipegang secara mendalam untuk membeli atau mendukung kembali produk atau jasa yang disukai di masa depan meski pengaruh situasi usaha pemasara berpotensi menyebabkan konsumen baralih. Menurut Jacob (1971) loyalitas didasarkan pada proses sikap untuk kembali yang bersumber atas kesadaran diri itu sendiri. Penelitian lain mengungkapkan bahwa suatu hasil proses dari sikap untuk memilih sesuatu yang paling disukai yang berdasarkan atas hasil konsistensi dalam jangka waktu tertentu (Assael, 1992, Keller, 1993). Menurut Keller
(1995) menyatakan bahwa loyalitas itu terjadi ketika sikap telah memilih sesuatu yang telah menjadi pilihan kemudian diwujudkan melalui perilaku untuk membeli pilihan tersebut. Menurut Engel, Kollat, dan Blackwell (1982) loyalitas merupakan merek sebagai "Respon yang istimewa, sikap dan perilaku terhadap satu atau lebih dalam kategori produk yang dinyatakan pada periode waktu oleh tertentu".

Berdasarkan definisi di atas, kesetiaan pelanggan dipandang sebagai kejadian non random, maksudnya apabila pelanggan mengetahui manfaat dari jasa tertentu dan manfaat ini sesuai dengan kebutuhannya, maka dapat dipastikan ia akan setia terhadap jasa tersebut.

Model yang dikonstruksi pada studi ini merupakan hasil konstruksian peneliti yang dihasilkan dari kajian literature studi terdahulu. Model penelitian ini menjelaskan pengaruh kualitas layanan terhadaployalitas konsumen. Model ini bertujuan untuk menguji hubungan pengaruh antara kualitas layanan berpengaruh terhadap loyalitas konsumen (H1), kualitas layanan berpengaruh terhadap kepuasan konsumen (H2), kualitas layanan berpengaruh terhadap e-trust (H3), kualitas layanan berpengaruh terhadap komitmen (H4), kepuasan konsumen berpengaruh terhadap loyalitas konsumen (H5), E-trust berpengaruh terhadap loyalitas konsumen (H6), komitmen berpengaruh terhadap loyalitas konsumen (H7). 


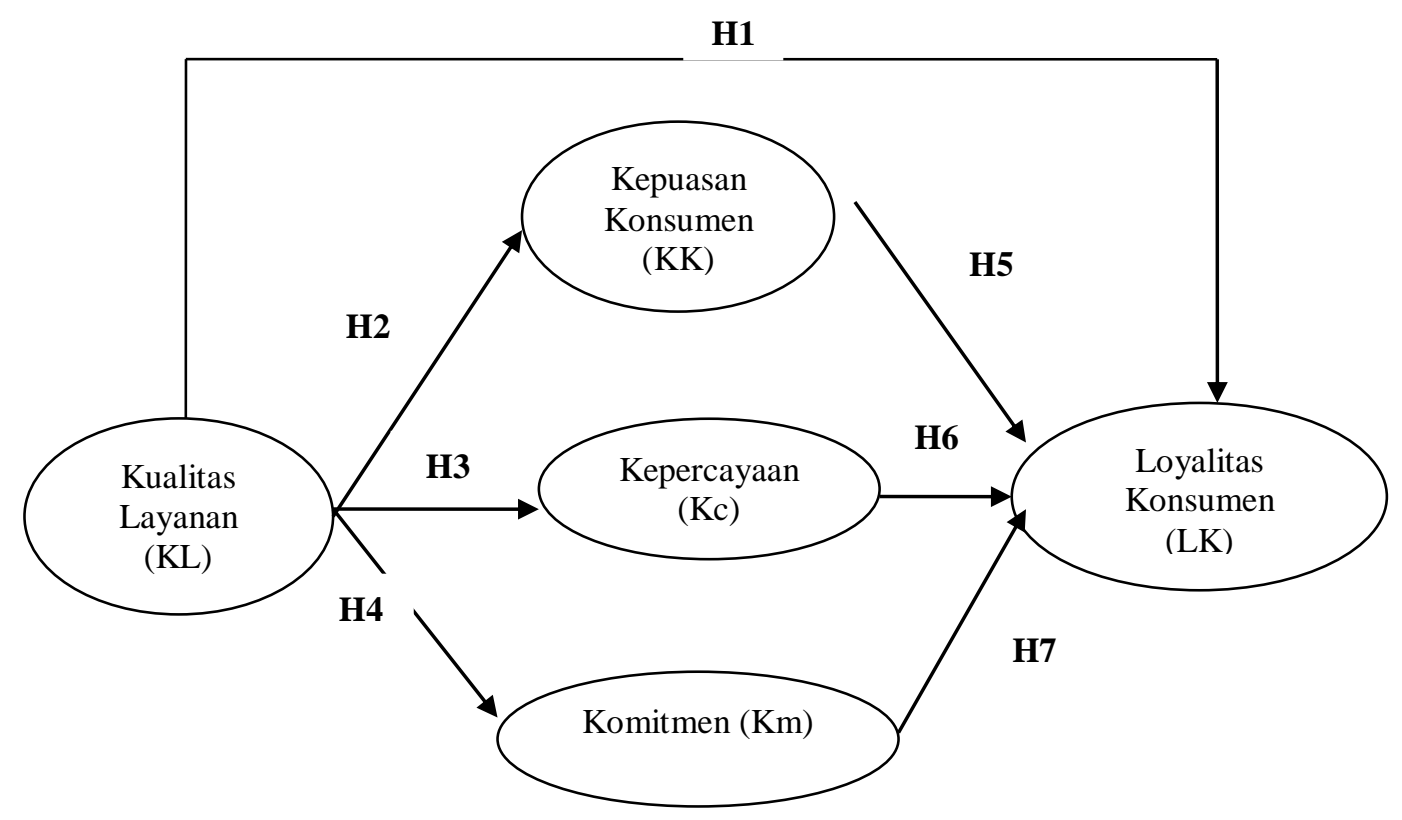

\section{METODE}

Gambar 1. Model Hipotesis

Populasi dalam penelitian ini adalah semua konsumen yang pernah menggunakan pembelian produk secara media online. Sedangkan sampel yang diambil di sini sebanyak 200 responden, penentuan jumlah sampel tersebut diharapkan memenuhi criteria maximum likelihood. Pengambilan sampel dalam penelitian ini dilakukan dengan menggunakan teknik purposive sampling dengan memilih sampel secara tidak acak dan sampel dipilih berdasarkan kriteriakriteria yang telah ditentukan. Teknik purposive sampling dipilih dengan tujuan untuk menghindari bias persepsi dalam pengisian kuesioner. Kriteria responden yang dipilih dalam studi ini adalah sebagai berikut: (1) pelanggan yang pernah menggunakan dan berniat untuk pembelian kembali dalam setiap pembelian produknya melalui media online shop (2) setiap responden yang mempunyai kesempatan sekali dalam pengisian kuesioner, (3) setiap responden berhak menerima atau menolak survei, dan tidak ada ikatan kekerabatan, intimidasi atau hadiah-hadiah dalam bentuk apapun yang dapat menurunkan derajat keyakinan tehadap kualitas data yang diperoleh, (4) setiap responden mengisi lembar kuesioner dengan lengkap secara online.

Teknik pengumpulan data dalam penelitian ini dilakukan melalui penyebaran kuesioner melalui fasilitas jejaring sosial misalnya Facebook, Twitter, ataupun media jejaring social lainnya.Hal ini dimaksudkan untuk memberikan kemudahan dalam pengambilan sampel guna memenuhi jumlah sampel yang telah ditetapkan

\section{HASIL DAN PEMBAHASAN Hasil Uji Hipotesis dan Pembahasan}

Dari tabel 1 Model Analisis SEM penelitian diperoleh koefisien-koefisien jalur, baik jalur langsung maupun jalur tidak langsung dapat ditampilkan sebagai berikut : 


\section{Tabel I}

Tabel Jalur Langsung Maupun Tak Langsung

\begin{tabular}{|c|c|c|c|c|c|}
\hline \multirow[t]{2}{*}{ No } & \multirow[t]{2}{*}{ Pengaruh } & \multirow[t]{2}{*}{ Terhadap } & \multirow[t]{2}{*}{ Jalur } & \multicolumn{2}{|l|}{ Pengaruh } \\
\hline & & & & $\begin{array}{l}\text { Tidak } \\
\text { Langsung }\end{array}$ & Langsung \\
\hline \multirow[t]{6}{*}{1} & \multirow[t]{7}{*}{$\begin{array}{l}\text { Kualitas Layanan } \\
(\mathrm{KL})\end{array}$} & $\begin{array}{l}\text { Loyalitas } \\
\text { Konsumen (LK) }\end{array}$ & - & - & 0,052 \\
\hline & & $\begin{array}{l}\text { Kepuasan } \\
\text { Konsumen (KK) }\end{array}$ & - & - & 0,490 \\
\hline & & Kepercayaan (Kc) & - & - & 0,374 \\
\hline & & Komitmen $(\mathrm{Km})$ & - & - & 0,645 \\
\hline & & \multirow{3}{*}{$\begin{array}{l}\text { Loyalitas } \\
\text { Konsumen (LK) }\end{array}$} & $\mathrm{KL} \rightarrow \mathrm{KK} \rightarrow \mathrm{LK}$ & 0,096 & - \\
\hline & & & $\mathrm{KL} \rightarrow \mathrm{Kc} \rightarrow \mathrm{LK}$ & 0,099 & - \\
\hline & & & $\mathrm{KL} \rightarrow \mathrm{Km} \rightarrow \mathrm{LK}$ & 0,291 & - \\
\hline 2 & $\begin{array}{l}\text { Kepuasan } \\
\text { Konsumen (KK) }\end{array}$ & $\begin{array}{l}\text { Loyalitas } \\
\text { Konsumen (LK) }\end{array}$ & - & - & 0,196 \\
\hline 3 & $\begin{array}{l}\text { Kepercayaan } \\
(\mathrm{Kc})\end{array}$ & $\begin{array}{l}\text { Loyalitas } \\
\text { Konsumen (LK) }\end{array}$ & - & - & 0,265 \\
\hline 4 & Komitmen (Km) & $\begin{array}{l}\text { Loyalitas } \\
\text { Konsumen (LK) }\end{array}$ & - & - & 0,451 \\
\hline
\end{tabular}

\section{Hasil Uji Hipotesis}

a. Pengaruh kualitas layanan terhadap loyalitas konsumen

Kualitas layanan berpengaruh positif terhadap loyalitas konsumen. Berdasarkan hasil pengujian menunjukkan bahwa kualitas layanan tidak signifikan berpengaruh pada loyalitas konsumen $(\beta=0,052 ; \mathrm{p}=$ 0,646) (lihat Tabel IV.15). Maka ini dapat disimpulkan bahwa Hipotesis 1 tidak didukung. Hal ini mengindikasi bahwa kualitas layanan tidak mempengaruhi secara langsung terhadap loyalitas konsumen, melainkan harus melalui kepuasan, kepercayaan, dan komitmen terlebih dahulu.

b. Pengaruh kualitas layanan terhadap kepuasan konsumen

Kualitas layanan berpengaruh positif terhadap kepuasan konsumen. Berdasarkan hasil pengujian menunjukkan bahwa kualitas layanan berpengaruh positif dan signifikan terhadap kepuasan konsumen $(\beta=$ 0,490; $\mathrm{p}<0,05$ ) (lihat Tabel IV.15). Maka ini dapat disimpulkan bahwa Hipotesis 2 didukung. Hal ini mengindikasi bahwa semakin baik kualitas layanan maka akan mempengaruhi secara langsung pada kepuasan konsumen.

c. Pengaruh kualitas layanan terhadap kepercayaan

Kualitas layanan berpengaruh positif pada kepercayaan. Berdasarkan hasil pengujian menunjukkan bahwa kualitas layanan signifikan berpengaruh pada kepercayaan $(\beta=0,374 ; \mathrm{p}<0,05)$ (lihat Tabel IV.15). Maka ini dapat disimpulkan bahwa Hipotesis 3 didukung. Hal ini mengindikasi bahwa semakin baik kualitas layanan akan mempengaruhi kepercayaan konsumen. 
d. Pengaruh kualitas layanan terhadap komitmen

Kualitas layanan berpengaruh positif pada komitmen. Berdasarkan hasil pengujian menunjukkan bahwa kualitas layanan berpengaruh positif dan signifikan terhadap komitmen konsumen $(\beta=0,645 ; \mathrm{p}<0,05)$ (lihat Tabel IV.15). Maka ini dapat disimpulkan bahwa Hipotesis 4 didukung. Hal ini mengindikasi bahwa semakin baik kualitas layanan yang diberikan maka akan semakin tinggi pula komitmen konsumen.

e. Pengaruh kepuasan konsumen terhadap loyalitas konsumen

Kepuasan konsumen berpengaruh positif pada loyalitas konsumen. Berdasarkan hasil pengujian menunjukkan bahwa kepuasan konsumen terhadap loyalitas konsumen berpengaruh positif dan signifikan pada loyalitas konsumen $(\beta=0,196$; $p<$ 0,10) (lihat Tabel IV.15). Maka ini dapat disimpulkan bahwa Hipotesis 5 didukung. Hal ini mengindikasi bahwa semakin tinggi kepuasan konsumen, maka semakin tinggi pula loyalitas konsumen tersebut.

f. Pengaruh kepercayan terhadap loyalitas konsumen

Kepercayaan berpengaruh postitif pada loyalitas konsumen. Berdasarkan hasil pengujian menunjukkan bahwa kepercayaan tidak signifikan berpengaruh pada loyalitas konsumen $(\beta=0,265 ; p<0,10)$ (lihat Tabel IV.15). Maka ini dapat disimpulkan bahwa Hipotesis 6 didukung. Hal ini mengindikasi bahwa semakin tinggi tingkat kepercayaan konsumen maka akan semakin tinggi pula tinggat loyalitas dari konsumen tersebut. g. Pengaruh komitmen terhadap loyalitas konsumen

Komitmen berpengaruh posititif pada loyalitas konsumen. Berdasarkan hasil pengujian menunjukkan bahwa komitmen terhadap loyalitas konsumen memiliki pengaruh positif dan signifikan pada loyalitas pasien $(\beta=$ 0,451; $\mathrm{p}<0,05$ ) (lihat Tabel IV.15). Maka ini dapat disimpulkan bahwa Hipotesis 7 didukung.Hal ini mengindikasi bahwa semakin tingggi komitmen konsumen maka semakin tinggi pula tingkat loyalitas konsumen tersebut.

h. Pengaruh tidak langsung melalui variabel perantara terhadap loyalitas konsumen

Maka dapat terlihat pengaruh tidak langsung suatu variabel terhadap variabel yang lain melalui variabel perantara (intervening variable). Adapun pengaruh variabel terhadap variabel yang lain secara tidak langsung adalah sebagai berikut :

- Pengaruh kualitas layanan terhadap loyalitas konsumen melalui variabel mediasi kepuasan konsumen sebesar 0,096. Ini artinya semakin baik kualitas layanan yang diberikan maka akan memberikan dampak pada kepuasan konsumen yang pada akhirnya dapat meningkatkan loyalitas konsumen.

- Pengaruh kualitas layanan terhadap loyalitas konsumen melalui variabel mediasi kepercayaan konsumen sebesar 0,099. Ini artinya semakin baik kualitas layanan yang diberikan maka akan memberikan dampak pada kepercayaan konsumen yang pada 
akhirnya dapat meningkatkan loyalitas konsumen.

- Pengaruh kualitas layanan terhadap loyalitas konsumen melalui variabel komitmen sebesar 0,291. Ini artinya semakin baik kualitas layanan yang diberikan maka akan memberikan dampak pada loyalitas konsumen yang pada akhirnya dapat meningkatkan loyalitas konsumen.

\section{PEMBAHASAN}

a. Pengaruh kualitas layanan terhadap loyalitas konsumen

Kualitas layanan berpengaruh positif terhadap loyalitas konsumen. Kualitas layanan didefinisikan secara umum bahwa perbedaan antara kedua ekspektasi konsumen pada layanan dan persepsi pada persepsi layanan (Gronroos, 1982; Parasuraman et al, 1988, 1991).

Kualitas layanan yang diberikan oleh pemasar atau perusahaan adalah suatu usaha yang dilakukan dalam upaya untuk dapat memberikan kepuasan dan loyalitas pada konsumennya. Hal ini mencangkup keramahtamahan, kegiatan, ketepatan, serta pertanggungjawaban bila terjadi kerusakkan pada produk yang sudah dibeli. Masalah ini sangat penting artinya bagi konsumen, oleh karena itu perlu mendapatkan perhatian yang sungguh-sungguh dari pemasar atau perusahaan.

b. Pengaruh kualitas layanan terhadap kepuasan konsumen

Kualitas layanan berpengaruh positif terhadap kepuasan konsumen. Kepuasan merupakan perasaan senang atau kecewa seseorang yang berasal dari perbandingan antara kesannya terhadap konerja atau hasil suatu produk dan harapan-harapnnya (Kotler, 2005).

Kepuasan konsumen merupakan evaluasi pembeli di mana alternatif yang dipilih sekurang-kurangnya sama atau melampaui harapan pelanggan, sedangkan ketidakpuasan timbul apabila hasil tidak memenuhi harapan (Tjiptono, 2004). Berdasarkan beberapa pengertian dari kepuasan konsumen dengan demikian sebagai pemasar harus memperhatikan kualitas dari layanan yang diberikan, karena sangat berpengaruh pada kepuasan konsumen yang akhirnya akan mempengaruhi loyalitas pembelian konsumen tersebut.

c. Pengaruh kualitas layanan terhadap kepercayaan

Kualitas layanan berpengaruh positif pada kepercayaan. Kepercayaan merupakan keyakinan bahwa penyedia jasa dapat menggunakannya sebagai alat untuk menjalin hubungan jangka panjang dengan konsumen yang akan dilayani. Kemampuan berkomunikasi yang efektif merupaakn instrumen untuk menghasilkan kepercayaan pelanggan, komunikasi yang efektif dapat membantu pelanggan untuk meningkatkan pengetahuan dan pemahaman tentang pentingnya menciptakan kepercayaan pada perusahaan penyedia jasa.

Dengan alasan itulah maka sebagai pemasar atau pun suatu perusahaan wajib untuk meningkatkan kualitas layanan sehingga dapat menumbuhkan kepercayaan bagi konsumen.

d. Pengaruh kualitas layanan terhadap komitmen

Kualitas layanan berpengaruh positif pada komitmen. Komitmen 
lebih terfokus pada komponen emosional atau perasaan. Komitmen terjadi dari keterkaitan pembelian yang merupakan akibat dari keterlibatan ego dengan kategori merek (Beaty, Kahle, Homer, 1998). Keterlibatan ego tersebut terjadi ketika sebuah produk sangat berkaitan dengan nilai-nilai penting, keperluan, dan konsep diri konsumen. Dalam membangun komitmen konsumen ini tidaklah mudah, ini harus dilakukan secara konsisten dan secara terus menerus oleh pemasar. Komitmen inilah yang menjadi salah satu indikator bagi pemasar untuk konsumen loyal terhadap produk.

e. Pengaruh kepuasan konsumen terhadap loyalitas konsumen

Kepuasan konsumen berpengaruh positif pada loyalitas konsumen. Loyalitas konsumen perlu diperoleh karena konsumen yang setia akan aktif berpromosi, memberikan rekomendasi kepada keluarga, teman, dan menjadikan produk tersebut sebagai pilihan utama, dan tidak mudah pindah. Dan para peneliti pun sepakat bahwa kepuasan konsumen merupakan faktor utama yang dapat menarik loyalitas konsumen.

f. Pengaruh kepercayaan terhadap loyalitas konsumen

Kepercayaan berpengaruh postitif pada loyalitas konsumen. Kepercayaan konsumen berkaitan erat dengan citra merek produk. Kotler (2000) mendefinisikan citra sebagai seperangkat keyakinan, ide, dan kesan yang dimiliki seseorang terhadap suatu obyek, sikap dan tindakan seseorang terhadap suatu obyek sangat dikondisikan oleh citra obyek tersebut. Ini berarti bahwa kepercayaan, ide, dan impresi seseorang sangat besar pengaruhnya terhadap sikap loyalitas konsumen.

g. Pengaruh komitmen terhadap loyalitas konsumen

Komitmen berpengaruh positif pada loyalitas konsumen. Komitmen merupakan salah satu indikator dalam mengukur tingkat loyalitas konsumen suatu produk. Melalui komitmen dapat diketahui keterkaitan pembelian yang merupakan akibat dari keterlibatan dari merek produk tertentu. Komitmen merupakan perasaan yang dirasakan oleh konsumen dari nilai-nilai yang diperoleh dari produk tersebut. Sehingga semakin baik nilai yang dirasakan oleh konsumen maka akan berpengaruh pada komitmen yang akhirnya akan meningkatkan loyalitas pada produk tersebut.

h. Pengaruh tidak langsung melalui variabel perantara terhadap loyalitas konsumen

Dari hasil pengaruh tidak langsung suatu variabel terhadap variabel yang lain melalui variabel perantara (intervening variable) maka dapat disimpulkan sebagai berikut :

Dari hasil masing-masing jalur pengaruh tidak langsung pada variabel kualitas layanan maka yang memiliki pengaruh paling besar terhadap loyalitas konsumen adalah kualitas layanan terhadap komitmen. Kemudian apabila dibandingkan pengaruh kualitas layanan secara langsung maupun tidak langsung terhadap loyalitas konsumen maka pengaruh tidak langsungnya lah yang lebih besar daripada pengaruh langsungnya. Ini berarti untuk meningkatkan loyalitas konsumen maka perusahaan harus 
meningkatkan kualitas layanan melalui komitmen pada konsumen.

\section{KESIMPULAN}

Loyalitas konsumen pada layanan online tidak dapat dicapai hanya dengan meningkatkan kualitas layanan semata, namun juga harus meningkatkan kepuasan konsumen, kepercayaan konsumen, dan komitmen. Dengan semakin baiknya kualitas layanan yang diberikan maka akan mempengaruhi secara langsung pada kepuasan konsumen. Dengan semakin baiknya kualitas layanan yang diberikan maka akan mempengaruhi secara langsung pada kepercayaan. Dengan semakin baiknya kualitas layanan yang diberikan maka akan mempengaruhi secara langsung pada komitmen. Dan yang kesemuanya tersebut pada akhirnya akan membentuk suatu loyalitas konsumen yang kuat.

Namun dari berbagai macam perantara mediasi yang digunakan untuk mencapai loyalitas konsumen online, variabel komitmen lah yang memiliki nilai terbesar dibanding variabel-variabel mediasi lainnya. Sehingga guna meningkatkan loyalitas konsumen online maka sebagai pemasar harus membangun kualitas layanan dan komitmen. Dengan ini diharapakan loyalitas konsumen dapat tercapai.

\section{DAFTAR PUSTAKA}

Anderson, R.E. and Srinivasan, S.S. (2003), "E-satisfaction and Loyalty: a contingency framework", Psychology and Marketing, Vol. 20 No. 2, pp. 12338.

Casalo, LV., C. Flavian and M. Guinaliu (2007). The role of security, privacy, usability and reputation in the development of online banking, Online Information Review, 31 (5): 583-603

Cha, J. (2011). Exploring The Internet As A Unique Shopping Channel To Sell Both Real And Virtual Items : A Comparison Of Factors Affecting Purchase Intention And Consumer Characteristics, Journal of Electronic Commerce Research, 12 (2): 115-132.

Christodoulides, G. and Michaelidou, N. (2010). Shopping Motives as Antecedents of E-satisfaction and E-loyalty, Journal of Marketing Management, 27 (1-2): 181-197

Chung, K.H and Shin, J.I. (2008). The Relationship among e-Retailing Attributes, e- Satisfaction and eLoyalty, Management Review: An International Journal, 3 (1): 23-45

Chung, K.H and Shin, J.I. (2009). The Relationship Between Site Characteristics, Relationship Quality, and Word of Mouth, International Journal of Business and Information, 4 (2): 137-160

Chung, K.H and Shin, J.I. (2010). The Antecedents and Consequents of Relationship Quality in Internet Shopping, Asia Pacific Journal of Marketing and Logistics, 22 (4), 473-491

Eid, M.I. (2011). Determinants of ECommerce Customer Satisfaction, Trust, and Loyalty in Saudi Arabia, Journal of Electronic Commerce Research, vol 12 (1),hal 78-93.

Gaur, S.S., Xu, Y., Quazi, A., and Nandi, S. 2011. "Relational Impact of Service Providers' Interaction Behavior In Healthcare". Managing Service Quality, Vol. 21 No. 1, pp. 67-87. 
Ghozali, Imam. 2005. "Aplikasi Analisis Multivariate Dengan Program SPSS Edisi 3". Semarang. Badan Penerbit Universitas Diponegoro.

Ghozali, I. (2006). Aplikasi Analisis Multivariate dengan program SPSS. Semarang : Badan Penerbit Universitas Diponegoro.

Gummerus, J., V. Liljander, M. Pura and A. van Riel (2004). Customer Loyalty to Content-based Web Sites: The Case of an Online Health-care Service, The Journal of Services Marketing, 18 (2/3): 175186.

Hair, Joseph., Anderson, Ralph E., Tatham, Ronald L dan Black, William C. 1998. "Multivariate Data Analysis”, New York : Prentice Hall Inc.

Hsin, Hsin Chang and Hsin-Wei Wang. (2010); "The Moderating Effect Of Customer Perceived Value Online Shopping Behaviour", Journal of Online Information Review, Vol. 35 No.2, pp.333-359

Horppu, M., Kuivalainen, O., Tarkiainen, A., and Ellonen, H-K (2008). Online Satisfaction, Trust and Loyalty, and The Impact of The Offline Parent Brand, Journal of Product and Brnad Mangement, Vol. 17 (6) hal 403-413.

Kassim, N. and Abdullah, N.A. (2010).

The Effect of Perceived Service Quality Dimensions on Customer Satisfaction, Trust, and Loyalty in e-Commerce Settings, Asia Pacific Journal of Marketing and Logistics, 22 (3): 351-371

Ki-Han Chung and Jae-Ik Shin. (2010); "The Antecedents And Consequents Of Relationship
Quality In Internet Shopping", Asia Pasific Journal Of Marketing and Logistics, Vol. 22 No. 2, pp. 473491

Liang, C.J. and Chen, H.J. (2009). A Study of the Impacts of Website Quality on Customer Relationship Performance, Total Quality Management, 20 (9): 971-988

Ling, K. C., Chai, L. T., and Piew, T. H. (2010). The Effects of Shopping Orientations, Online Trust and Prior Online Purchase Experience toward Customers' Online Purchase Intention, International Business Research, vol 3 (3), hal 63-76.

Maditinos, D. I., and Theodoridis, K (2010). Satisfaction Determinants In The Greek Online Shopping Context, Information Technology and People, vol 23 (4), hal 312329.

Parasuraman A, Zeithaml VA, Berry LL. (1988). "SERVQUAL: a multipleitem scale for measuring consumer perceptions of service quality". Journal of Retailing, 64(1): 12-40.

Parasuraman, A., Zeithaml, V. And Malhotra, A. (2005), "E-S-QUAL a multiple-item scale for assessing electronic service quality", Journal of Bussiness Research, Vol. 7 No. 3, pp. 213-33

Park, CH and YG. Kim (2003). Identifying Key Factors Affecting Consumer Purchase Behavior in an Online Shopping Context, International Journal of Retail and Distribution Management, 31 (1): 16-29.

Pin Luarn; " A Customer Loyalty Model For E-Service Context”, 
Departement Of Business Administration.

Sheng, T., and Liu, C. (2010). An Empirical Study On The Effect of E-service Quality On Online Customer Satisfaction and Customer Loyalty, Nankai Business Review International, 1 (3): 273-283.

Wolfinbarger, M.F. and Gilly, M.C. (2003). "E-Tail: Dimensionalizing, Measuring and Predicting etail quality", Journal of Retailing, Vol. 79 No. 3, pp. 183-198. 